\title{
Wensong Bai
}

Assistant Professor/Post-doc Researcher/ Post-doc Researcher

Department of Innovation, Entrepreneurship and Investment Management/ School of Technology and Business Studies/ Department of Business Studies Zhejiang University of Technology/ Dalarna University/ Uppsala University

18, Chaowang Road, Hangzhou (China)

Phone: + 86-571-88320457; Fax: +86-571-88320272

Martin Johanson

Professor

Dalarna University/ Uppsala University

School of Technology and Business Studies/ Department of Business Studies

78170 Borlänge (Sweden)

Phone: +46 023 778050; Fax: +46023 778050

E-mail: mjoh@du.se

Oscar Martín Martín

Associate Professor/ Associated Researcher

Public University of Navarre/ Institute for Advanced Research in Business and Economics

(INARBE)/ Uppsala University

Department of Business Administration / Department of Business Studies

Campus Arrosadía s/n, 31006 Pamplona, Navarre (Spain)

Phone: +34 948166082

E-mail: oscar.martin@unavarra.es 


\title{
Dual business relationships, opportunity knowledge, and new product development: A study on returnee young ventures
}

\author{
Abstract \\ The effects on innovation of the dual embeddedness of returnee young ventures (RYVs) in \\ both domestic and international networks of relationships and knowledge contexts are \\ important for value creation, growth, and success of these firms and embody a unique \\ research opportunity. Based on a framework combining a business relationship perspective \\ and the knowledge-based view, we propose that RYVs take advantage of business \\ relationships and opportunity knowledge from both international and domestic markets to \\ nurture their innovation. We test our model on a sample of 200 RYVs in China. The \\ findings reveal that business relationships are essential for acquiring knowledge about \\ technological and business opportunities, although only international opportunity \\ knowledge and domestic business relationships positively influence new product \\ development. In addition, the interaction between international and domestic business \\ relationships constrains firms' capacity for obtaining international opportunity knowledge. \\ Our study offers insights into how the trade-offs between dual relationships and \\ subsequently sourced knowledge contribute to new product development in emerging \\ markets, and it extends the discussion on the paradox view of business relationships with \\ geographically dispersed actors.
}

Key words: Returnee young ventures, domestic and international markets, business relationships, opportunity knowledge, new product development, networks 


\section{Dual business relationships, opportunity knowledge, and new product development: A study on returnee young ventures}

\section{INTRODUCTION}

For most small and medium-sized firms operating in global markets, the development of new products is critical for value creation, growth, and success. This is also the case for returnee young ventures (RYVs), which is a recent phenomenon that is increasingly drawing attention from both researchers and practitioners. Because they are firms whose founders accumulate knowledge abroad and then start a new venture in their home country (Lin et al. 2016; Fernhaber, McDougall-Covin, and Shepherd 2009), they most often operate in both domestic and international markets, where they may be able to take advantage of dual business relationships and the access to the knowledge they provide. A central idea in the literature on RYVs is that they are transferors of social capital and knowledge across markets (Liu, Lu et al. 2010). Importantly, their business relationships and knowledge have implications for venture creation, innovation, and growth. First, returnee firms' local ties are seen as indispensable for venture creation (Pruthi 2014), or at least they make it more likely (Qin and Estrin 2015). International knowledge transfer affects their entrepreneurial decisions (Lin et al. 2016) as well. Second, RYVs are more innovative than their local counterparts (Liu, Wright et al. 2010). Third, these young ventures have disadvantages in terms of domestic connections and knowledge (Li et al. 2012), although international knowledge and networks drive the growth of their sales and performance (Dai and Liu 2009).

Previous returnee studies that either focus on the role of international business relationships and the knowledge derived from them (Dai and Liu 2009; Liu, Lu et al. 2010) 
or emphasize the domestic business relationships (Lin et al. 2019) have not examined RYVs' simultaneous embeddedness in two networks of relationships and knowledge contexts. This gap represents an interesting research opportunity (Lin et al. 2019). First, international marketing and entrepreneurship literature calls for a better understanding of how the characteristics of RYV contribute to innovation (Yang and Gabrielsson 2018). Arguably, the broader access to both international and domestic relationships and knowledge is the most salient feature (Lin et al. 2019; Liu, Wright, and Filatotchev 2015), and the effectiveness of a firm's innovation performance can be fully realized through its activities both at home and abroad (Patel and Conklin 2009).

Second, international marketing literature indicates that the nature and quality of a firm's business relationships influence knowledge. However, the international and domestic relationships, as well as the knowledge gained in domestic and international contexts, may have a different impact on a firm's development of new products (Patel et al. 2014; Zhang et al. 2010). Thus, a relevant research question relates to the precise composition of young ventures' business relationships (Samiee, Chabowski, and Hult 2015). To develop a strategy, the firm must put its time and effort into the different facets of business relationships effectively. The international and domestic facets of relationship configurations is one such important factor to be considered by firms in the era of “glocalization” (Chen and Tan 2009).

With the aim of bridging this research gap, this study attempts to extend previous research by examining the influences of international and domestic business relationships and opportunity knowledge derived from them on new product development of RYVs. We build our study on the literature that argues that international growth is a function of business relationships and opportunity development (e.g., Johanson and Vahlne 2009; 
Oviatt and McDougall 2005), and assume that domestic and international business relationships are different in nature and thereby produce opportunity knowledge with different origins and characteristics. Accordingly, the purposes of this study are to analyze (i) whether international and domestic business relationships and knowledge may explain new product development, and (ii) how these different types of relationships can contribute to or inhibit the acquisition of international and domestic opportunity knowledge.

This study contributes to returnee entrepreneurship and international marketing literature in two ways. First, we extend the existing conceptual and empirical understanding of RYVs, which mainly focuses on relationships with a single geographical origin. By examining the configuration of international and domestic relationships as key drivers of their product development, we provide a more complete spatial account of the dual business relationships of RYVs. In particular, we uncover the direct and indirect mechanisms through which the dual business relationship advantage is conducive to RYVs' innovation.

Second, we add to the understanding of the effect mechanisms of international and domestic relationships. A trade-off exists and needs to be considered in the balanced configuration of business relationships (Chen and Tan 2009; Patel et al. 2014), especially for young ventures from emerging markets (e.g., RYVs) that rely on internationally sourced knowledge. Accordingly, our study provides new insights into the paradox view of business relationships (Gao, Ren, and Miao 2018) by encapsulating the pursuit of both international and domestic business relationships for product development (Knight and Cavusgil 2004). Specifically, the interaction between international and domestic business relationships constrains firms' capacity for obtaining international opportunity knowledge and thus challenges previous literature that takes a balanced view of dual relationships. 
In the next section, we present the theoretical foundations of the paper. In the third section, we propose a model and develop nine hypotheses that explain the relationship between business relationships, opportunity knowledge, and new product development. The fourth section presents the methodology, and the fifth presents the findings. These are subsequently discussed in the sixth section. The paper concludes by considering the implications for scholars and practitioners, the limitations, and future research areas.

\section{THEORETICAL FRAMEWORK}

\section{Business relationships}

The business relationship perspective has been increasingly adopted in marketing and entrepreneurship research, and has primarily been used as a lens to understand the innovative efforts of ventures (Hoang and Antoncic 2003). The highlighting of interaction and coordination in studies of innovation reflects this trend (e.g., Yli-Renko and Janakiraman 2008), and studies of firms' behavior suggest the role of business relationships in accessing external resources (e.g., Patel et al. 2014; Shu et al. 2012). Whereas young ventures are market entrants and suffer from the liability of newness, business relationships provide benefits in terms of information, knowledge, and opportunities.

Relationships embody long-term resource exchange (Ju and Gao 2017), which makes up a specific governance mode characterized by trust, commitment, interdependence, and reciprocity (Hoppner, Griffith, and White 2015; Leonidou et al. 2014). This enables firms to understand the norms and values that prevail in the network, which in turn leads the firms to adapt to and fit with their partners in the network (Coviello 2006). On top of that, the business relationships create opportunities tailored for firms in the network (Hoang and 
Antoncic 2003). Thus, extraction of value from the network has been conceptualized as an economic behavior embedded in social relations.

\section{Dual business relationships and returnee young ventures}

Despite relationships being borderless (Johanson and Vahlne 2009), international marketing and business literature commonly distinguishes between domestic and international business relationships, referring to relationships either with partners in the domestic market (e.g., Zhou, Wu, and Luo 2007) or with partners in the international market (e.g., Ellis 2011). Literature has highlighted the importance of each of them in the innovation process of young ventures but has rarely considered their configuration jointly (Patel et al. 2014).

Through international business relationships, ventures receive the inflow of highly specialized and novel knowledge, which is often not related to the current knowledge base and which they are not able to find domestically (Zhang et al. 2010). In particular, international business relationships represent an efficient means for acquiring current and specific knowledge regarding international competitors' movement and customer needs, therefore benefiting the development of a commercially viable and culturally adaptable product for the international marketplace (Patel et al. 2014). Accordingly, literature has indicated that knowledge sourced through international business relationships plays a more important role in facilitating innovation than does knowledge from domestic business relationships (Zhang et al. 2010), despite the significant costs and commitment required to develop such international business relationships (Patel et al. 2014).

Although the literature tends to highlight the value of knowledge gained abroad because of its newness (Levin and Barnard 2013), domestic business relationships also matter for new product development. Firms operating closely with domestic business 
relationships enjoy proximity of collaboration, which makes face-to-face contact more feasible. This enhances the exchange of tacit information and the interactive process of product development (Yli-Renko and Janakiraman 2008). More importantly, domestic business relationships create a cost-efficient competitive advantage for new product development by providing collective efficiencies that offset young ventures' resources and infrastructure insufficiency (Patel et al. 2014). In other words, young ventures can pool their resources (for instance, by sharing product development laboratory, production plants, or logistics) to achieve economies of scale.

With globalization and recent advances in communication technologies, young ventures learn to identify opportunities by interacting with customers and suppliers in both domestic and international networks (Patel et al. 2014). RYVs reflect this advantage that positively impacts innovations (Liu, Lu et al. 2010). Returnee entrepreneurs usually have spent several years in OECD countries (Wright et al. 2008), and their educational background and international experience constitute human capital and knowledge, which are exploited as advantages in relation to indigenous firms in the domestic market. The returnee entrepreneurs' knowledge of Western science and technology and of the business community gives them access to international R\&D partners (Lin 2010).

RYVs' greater access to technological knowledge and managerial skills compared to firms in home markets does not always lead to enhanced competitiveness ( $\mathrm{Li}$ et al. 2012). This may be because RYVs, besides suffering from the liability of newness, also suffer from the liability of returning to their domestic market (Li et al. 2012). The entrepreneurs are absent from the domestic market for years, and as many of these countries are growing emerging markets, the RYVs' knowledge about them needs to be updated. This can be accomplished through the development of a domestic network. Domestic business 
relationships are partly developed based on the returnee entrepreneurs' pre-overseas local relationships, or partly built on their local partners' relationships (Lin et al. 2019). Meanwhile, there are relationships that are developed further by the RYVs' business efforts after they are created in the domestic market. But the issue is that the more active RYVs become in domestic business networks, the less time and fewer resources will be left for the maintenance of international business relationships, and vice versa. Similar trade-offs between global and local responses have been identified even in large multinational corporations (Andersson et al. 2016). They could be particularly notable in RYVs, given their scarce internal managerial resources (Lin et al. 2019).

\section{Opportunities, opportunity knowledge, and new product development}

Opportunities have been conceptualized as "situations in which new goods, services, raw materials, markets and organizing methods can be introduced" (Eckhardt and Shane 2003, p. 336) and represent a high degree of novelty or originality that produces more value than existing means. Opportunities are, therefore, situations where there is a favorable set of circumstances to create value (Chetty, Karami, and Martín Martín 2018).

The development of opportunities is not an activity that takes place separately from business networks (Johanson and Vahlne 2009). It is an interactive process where the supplier and the customer gradually and sequentially learn and commit to opportunities emerging from both domestic and international business relationships (Johanson and Vahlne 2009, p. 1420). Thus, in agreement with Knight and Liesch (2016), we contend that opportunities are knowledge-based, and particularly linked with firms' prior knowledge. This is in line with the original article on internationalization, Johanson and Vahlne (1977, p. 27), which emphasized the connection between knowledge and opportunities. 
In this study, we define opportunity knowledge as the knowledge about the market and about novel ideas and business opportunities. Opportunity knowledge encompasses, therefore, both knowledge about ideas and business opportunities and knowledge about market aspects and situations. It emerges through coordination and cooperation in relationships with other firms (Laursen and Salter 2006) and contributes to opportunity development. Knowledge about different opportunities and favorable sets of circumstances to create value is of critical importance for firms. Accessing and integrating opportunity knowledge complements firms' extant knowledge by reducing the risk of blind spots and unexpected technological change (Laursen and Salter 2006; Leiponen and Helfat 2010), and, therefore, enhances the odds for success in new product development.

Changing international markets in recent decades have exposed firms to pressure to adapt, which highlights the importance of innovation for new product development. Innovation literature has been documenting the important role of knowledge in promoting firms' new product development (Laursen and Salter 2006). Yet, the same knowledge base may result in competency traps that impede innovation (Levinthal and March 1993). Therefore, new product development is often a result of the combination of diverse knowledge (Patel et al. 2014), which requires knowledge acquired beyond organizational boundaries (Chatterji and Fabrizio 2014). For many firms, especially young entrepreneurial firms, the acquisition of knowledge and resources through business relationships becomes critical (Yli-Renko and Janakiraman 2008).

Firms may obtain or develop opportunity knowledge along different geographical horizons, of which domestic business relationships and international business relationships are two possibilities (Patel et al. 2014; Wu and Wu 2014). Knowledge takes on marketspecific characteristics and reflects differences in culture, technological development, 
resource endowments and industry structure, and regulatory environment. In other words, the conditions of each market generate a distinct system of knowledge (Patel et al. 2014) and the variation across the markets compels firms to find knowledge and technical ideas across borders for innovation ( $\mathrm{Wu}$ and $\mathrm{Wu} 2014)$.

\section{MODEL AND HYPOTHESIS DEVELOPMENT}

We combine a business relationship perspective and the knowledge-based view to propose a model explaining the effects of business relationships and opportunity knowledge from both international and domestic markets on RYVs' new product development. Figure 1 illustrates the model and the nine relationships that we hypothesize below.

\section{"Figure 1 goes about here"}

\section{Business relationships and opportunity knowledge}

Business relationships are based on intensive and frequent exchanges between firms, where they develop mutual adaptations and make relationship-specific investments (Skarmeas, Zeriti, and Baltas 2016). They emerge through social interaction characterized by cooperation and interdependence (Uzzi 1997) and go through a process starting with their establishment, which after a while may be followed by extensive cooperation, resulting in trust and commitment (Paparoidamis, Katsikeas, and Chumpitaz 2019).

Cooperation enables firms to understand their business partners, which in turn improves mutual learning and adjustment. Benefiting from this tacit understanding, firms obtain more refined information, such as technology and non-codified knowledge, from business partners. Furthermore, the informal governance mechanism of relationships grants 
firms legitimacy in networks (Rao, Chandy, and Prabhu 2008), which results in a referral effect (Uzzi 1997). Firms can have exchanges not only with their direct counterparts but also with, indirectly, the counterparts' direct counterparts, so that there is a flow of knowledge from other sources in the network that stretches beyond the direct relationships.

This means that business relationships are instrumental in the identification and creation of business and technological opportunities and ideas. Firms with strong business relationships are more likely to exchange knowledge about these business and technological opportunities and ideas (Johanson and Vahlne 2009). Consequently, the more closely a firm cooperates with and solves problems with its business partners, the more likely that firm is to acquire novel knowledge and identify and create opportunities. As knowledge is a critical resource and opportunities "constitute a subset of knowledge" (Johanson and Vahlne 2009, 14), business relationships enlarge the firm's scope when it comes to seeking knowledge and exploring opportunities that are out of its individual reach.

The network consists of relationships between suppliers, customers, competitors, and other business intermediary service firms (see Zhou et al. 2007), and the business relationships provide new knowledge and resources to nurture the firm's knowledge (Pruthi 2014). Because knowledge is a product of social interaction and is tacit and accessible only to those active within the network (Sheng, Zhou, and Li 2011; Shu et al. 2012), it is intertwined with the network in which it emerges (e.g., domestic vs. international business relationships), that is, it is market-specific (Patel et al. 2014).

Accordingly, firms utilize business relationships with partners in the domestic market network, which results in the generation and release of specific opportunity knowledge (Johanson and Vahlne 2009). For example, the domestic business relationships are helpful for acquiring opportunity knowledge from governments, which comprise the primary 
source of business opportunities in emerging markets (Armanios et al. 2017). International business relationships, on the other hand, are among technology providers, and from these, marketing, technological, and competitive information is procured, which leads to increasing technological learning (Knight and Cavusgil 2004). In light of the fact that RYVs develop both domestic and international business relationships, and considering that each type of business relationship may facilitate the sharing of knowledge about business partners and market information in different sorts of markets, we posit that:

HIa: Returnee young ventures' domestic business relationships are positively associated with the obtaining of domestic opportunity knowledge.

H1b: Returnee young ventures' international business relationships are positively associated with the obtaining of international opportunity knowledge.

If one assumes that business relationships are embedded in networks, they differ owing to the cultural and institutional contexts (Chan and Tan 2009; Patel et al. 2014). Thus, business relationships vary in nature between domestic and international markets, and this heterogeneity may require different skills and resources for RYVs in each network (Gao, Ren, and Miao 2018). We contend that making efforts to be active in both domestic and international business relationships may hamper opportunity knowledge. In particular, obtaining opportunity knowledge from either domestic or international business relationships implies intensive exchanges and cooperation within that type of business relationship. Hence, dealing with dual facets of relationships at the same time becomes demanding in terms of managerial attention and other resources. This is challenging even 
for large multinational corporations (Andersson et al. 2016), not to mention RYVs suffering from liabilities of newness and smallness. Therefore, devoting themselves to being active in dual business relationships simultaneously may constrain RYVs' capacity to obtain opportunity knowledge from each of the business relationships. We posit that:

H1c: The interaction of returnee young ventures' international and domestic business relationships is negatively associated with the returnee young ventures' obtaining of international and domestic opportunity knowledge.

\section{Opportunity knowledge and new product development}

By acting in business networks, RYVs acquire opportunity knowledge from and with other business partners in the network, which is conducive to new product development. First, the opportunity knowledge can be integrated into the firms' research and development activities. They stimulate the innovation process, where the new business opportunities and ideas gained through business relationships inspire and guide what future product is needed and what is perceived to be of value by the business partners in the network. As such, RYVs foresee new market demands and can decide what could be worth investing resources in promptly.

Second, opportunity knowledge provides new technological ideas about how to shape new product development and therefore enhances the firm's awareness and understanding of relevant technological know-how that is applied in new product development. This may benefit the firm's R\&D capability updates and lead to the involvement of the latest and relevant technology in new product development. 
Third, the skills and knowledge needed to promote and sell a product through the business relationships are essential to product development. This knowledge includes what kinds of technical features products should have in order to attract and maintain relationships with customers, and in what manner the new products can be delivered to them. By integrating the opportunity knowledge derived from business relationships with existing innovative knowledge, firms can rapidly react in response to business opportunities and develop new products, and the likelihood increases that the firm can make an innovation breakthrough and bring the new products and technology to the market quickly.

More importantly, knowledge with different geographical origins differs to some degree in its content. Returnee young ventures' founders bring international vision, marketing knowledge, and original technology and product development capabilities to their firms, which enables the firms to develop and introduce novel products to markets. There are subtle socio-economic, cultural, and historical differences between markets, which are reflected in the customers' attitudes toward and acceptance of new products. Opportunity knowledge gained in domestic business relationships thus enables firms to update their understanding of the trends and needs in the domestic market.

In contrast, internationally gained opportunity knowledge is often related to technological change and development in international markets. As high-tech industries are characterized by dynamic and fast change, RYVs are likely to keep an eye on changes in international markets and learn about the latest progress of foreign $R \& D$ partners. Internationally gained opportunity knowledge is likely to be novel or provide new perspectives on applying the same technology (Patel et al. 2014). Based on the above reasoning, it is thus hypothesized that: 


\begin{abstract}
H2a: Returnee young ventures' domestic opportunity knowledge is positively associated with new product development.
\end{abstract}

\begin{abstract}
H2b: Returnee young ventures' international opportunity knowledge is positively associated with new product development.
\end{abstract}

Furthermore, opportunity knowledge regarding new business opportunities and technology advancement, from operating both in international high-technology networks and in the domestic network, are likely to have a joint effect on product development. Particularly, a combination of a broader and more diversified knowledge base (e.g., international vs. domestic opportunity knowledge) is helpful for handling competency traps (Levinthal and March 1993). Although firms building on either international or domestic opportunity knowledge are likely to improve their products and develop competitive advantage in a particular domain ( $\mathrm{Wu}$ and $\mathrm{Wu} 2014$ ), such product development is, after all, limited to the particular knowledge domain, leading to the formation of core rigidities (Levinthal and March 1993). As a result, the firm may become less able to recognize and appreciate the significance of new technology and novel product ideas generated outside that knowledge domain and may therefore fall behind in relevant technology development. The competency trap issue will become more problematic when dealing with unexpected technological discontinuity (Wu and $\mathrm{Wu} 2014$ ) and unpredictability in market demand (Ju, Jin, and Zhou 2018), which is often the case in industries characterized by dynamic and complex technology changes (Leiponen and Helfat 2010).

In contrast to this, the international opportunity knowledge, coupled with domestic opportunity knowledge that gives RYVs a more thorough understanding of the domestic 
market, helps RYVs keep track of new technology development and generate new product ideas that are viable for different market contexts, and inspires their innovative capability to upgrade accordingly (Patel et al. 2014). Consequently, receiving heterogeneous knowledge about opportunities reinforces each other's effects on promoting new product development: the more knowledge sources a firm has, the more potential ways it has to combine the different aspects of knowledge. Accordingly, we posit that:

H2c: The interaction of domestic and international opportunity knowledge is positively associated with new product development.

\section{Business relationships and new product development}

Interfirm business cooperation in relationships has a strong impact on performance (Katsikeas, Skarmeas, and Bello 2009), and product development is often a function of business relationships (Yli-Renko and Janakiraman 2008). Besides knowledge exchange and joint learning, business relationships generate other beneficial conditions that favor innovation activities. Cooperation within business relationships entails the combining of complementary resources between business partners (Robson et al. 2019). It is often the case that neither firm in the relationship possesses all relevant resources for the development of new products. These resources are usually also rare and inimitable, which means that they are seldom readily available in the market, and it takes time to develop and accumulate them. Not surprisingly, then, RYVs are less likely to possess sufficient resources within their boundaries, but through their business relationships, they have access to and are able to use the resources of business partners. 
In particular, RYVs have often developed strong basic research capabilities based on the founders' knowledge. This is complementary to the long-established manufacturing and distribution capabilities of their partners in the domestic market (Kenney, Breznitz, and Murphree 2013). Additionally, domestic business partners have specialized expertise in technology service (Zhang and Li 2010) and provide assistance such as intellectual property application and so on (Armanios et al. 2017). Accordingly, the cooperation between the domestic business partners enables firms to bring new and competitive products to market in a short space of time and with a broad scope.

Moreover, business relationships provide incentives for partners to share their specialized resources, as they believe that the relationships are long-term and that those specialized resources will not be duplicated by their counterparts. Therefore, they may like to augment the investment in relation-specific assets, such as the complementary resources customized to RYVs. The investment and sharing of specialized assets, in turn, enhance new product development in two ways. First, the enhanced accessibility of more tailored resources enables the firm to better exploit its research capabilities in the domestic market. Second, such accessibility lowers the cost and increases the speed of new product development. Since RYVs have access to complementary resources readily available in networks of business relationships, they do not have to face transaction costs such as those associated with searching for and negotiating with suppliers in arm's-length markets.

Similarly, international business relationships provide complementary resources that facilitate product development, albeit distant from RYVs' current domestic markets. In particular, there may be some research capabilities that are only available by way of international R\&D partners yet are necessary for solving problems related to technology, 
which thus requires that RYVs work closely with international partners. Based on this reasoning, we therefore hypothesize that:

H3a: Returnee young ventures' domestic business relationships are positively associated with new product development.

H3b: Returnee young ventures' international business relationships are positively associated with new product development.

On top of that, the joint effects of international and domestic relationships may demonstrate greater influence on RYVs' innovation than their individual effects (Patel and Conklin 2009). Specifically, the configuration of the relationships may provide a more modular search setting, whereby the resource search process becomes more efficient (Patel et al. 2014). Also, the joint effects may bridge resources, technology, and human capital across borders and give rise to broader choices in terms of resource combination. Such an increased diversity in available resources, and a better pool of combinations to select from, generate flexibility and mobility of RYVs' innovative efforts and enhance the odds of finding a more appropriate combination of resources (Patel et al. 2014).

In addition, the business relationships are distributed into two contexts that are often different in terms of institutions and culture. Normally it requires time and effort to develop an understanding of the distinct norms, values, and routines across the different business relationships before the firm can tap into resources embedded in different relationships. Nevertheless, RYVs may, to some extent, have an advantage in such situations due to their returnee founders' international mobility experiences (Liu et al. 2015). Different rules also 
imply unique opportunities that enable RYVs to innovatively combine resources for new product development (Patel and Conklin 2009). Therefore, we posit that:

H3c: The interaction of domestic and international business relationships is positively associated with new product development.

\section{METHODOLOGY}

\section{Sample and data}

The empirical study on RYVs was carried out in the Pearl River Delta Economic Zone, one of the most developed regions in China and one of the top three destinations for Chinese returnee entrepreneurs (Wang and Miao 2013). Specifically, we focused on RYVs in Shenzhen, Guangzhou, Dongguan, Zhuhai, Zhongshan, and Foshan. The Administrative Committee of the returnee entrepreneurial business park in each city provided a list of returnee firms; to those lists we added additional returnees we identified through the Internet. The initial list of RYVs consisted of 1,915 businesses, most of them located in the two large cities (Shenzhen, 738, and Guangzhou, 726) and with a smaller presence in the other four (Dongguan, 220; Zhuhai, 111; Zhongshan, 25; and Foshan, 95).

We contacted the 1,915 RYVs, explained the purpose of the study, and applied three sampling criteria to identify firms suitable for our research project. We could then confirm (1) that a returnee had created the firm, (2) that the firm had been in business for over two years (so there was a minimum time frame for its operations), and (3) that the RYV was involved in international operations (so the firm was not operating only in the domestic market and it had up-to-date international knowledge). Thus, we obtained an all-inclusive sample of $836 \mathrm{RYVs}$, which we invited to participate in our study. A total of $201 \mathrm{RYVs}$ 
completed the survey after two rounds of visits. There was only one large firm in the sample, and we decided to discard it in order to keep a high level of size homogeneity and to enhance comparability of the firms used in the analyses. According to the Chinese definition of SME, most firms (165, or 82\%) were small, with a lower number of micro(16) and medium-sized (19) firms. The mean number of employees in the 200 returnee firms used is 37.35 with a mean turnover of RMB 22.99 million.

Irrespective of their young age (4.4 years on average), these firms adopted internationalization at an early stage and each had entered an average of 5.6 foreign markets. A large number of the returnee young ventures (67\%) first targeted the host country where the returnee entrepreneur previously lived. The USA (48\%) and the UK $(15 \%)$ were the most frequent cases. This is in line with the fact that the most popular hosting countries for returnees in our sample are the US (92) and the UK (31). The average length of time returnee entrepreneurs spent abroad is 7.82 years. Appendix 1 presents key features of the sample used in this study.

\section{Questionnaire and field research}

The structured questionnaire responded to the research objectives and considered relevant literature on returnee entrepreneurship, international marketing, international entrepreneurship, innovation, SMEs, and networks. It was designed in English. Two researchers reviewed the first draft and made minor changes. The questionnaire was subsequently translated into Chinese. Two Chinese scholars reviewed the Chinese version of the questionnaire and made a back translation. After a few minor modifications, the questionnaire was pretested in China with four returnee entrepreneurs. The pretest helped to eliminate ambiguous content. 
We organized the field research in the following ways in order to control the quality of the responses. We trained a survey team consisting of one of the authors and five experienced enumerators. They visited each firm and interviewed the returnee entrepreneurs after explaining the purpose of the study. To increase participation, we had a referral letter from a Chinese university vouching for the legitimacy of our research project. The founders of the firms completed the questionnaires, which took about 25-35 minutes. After the two rounds of visits carried out between October 9, 2013, and January 21, 2014, we collected the 201 valid questionnaires, with a response rate of $24 \%$. There are no significant differences between early and late respondents nor between respondents and non-respondents in terms of firm age and size.

The pretest helped us to prevent common method variance (Chang, van Witteloostuijn, and Eden 2010) by avoiding unclear, vague, and unfamiliar terms in the formulation of questions and indicators. In addition, we randomly selected 30 sample returnees and asked an alternative senior executive to complete the survey at each firm. When these were compared to the original survey responses by the returnee, the results suggested that the responses of the two executives from the same company were highly consistent $($ Pearson correlation $=0.80)$. Further, in a post-survey stage, we called back 55 original respondents to check their response accuracy, and the results showed high consistency between their telephone interview reports and the survey answers.

Finally, we carried out a series of diagnostic and ex-post statistical tests to check for biases not minimized by the research design. First, we implemented a single-method-factor approach (Podsakoff et al. 2003). We performed a confirmatory factor analysis (CFA) by letting manifest indicators load on both the latent CMV factor and their respective theoretical constructs. The results showed that the loadings of all items were still significant 
after the inclusion of the CMV factor. Second, we used a CFA marker technique. Following Williams, Hartman, and Cavazotte's (2010) approach, we took a marker construct (Returning with non-business motivation) from the large dataset. The marker construct was theoretically unrelated to the constructs in question in this study. We estimated a series of models (see Appendix 2) and compared the change in fit among these models (Williams et al. 2010). In particular, we were able to ascertain whether the correlations of investigated constructs were significantly biased based on the comparison of the Method-U and Method$\mathrm{R}$ models. Because the Chi-square difference between the Method-U and Method-R models is 12.43 (lower than the 0.05 chi-square critical value for 14 degrees of freedom of 23.68), we can claim that the estimated constructs' correlations do not suffer from significant bias. In conclusion, the research design and the ad hoc analyses point to a limited likelihood of common method bias in our data.

\section{Operationalization of the variables}

The operationalization of the variables is presented in Table 1. In order to measure international and domestic business relationships and opportunity knowledge and new product development, we focused on the last three years.

Business relationships. We measured "domestic business relationships" based on three indicators. The first one reflects the extent to which the firm has developed business relationships with other business actors in the domestic market: specifically, the extent to which the firm (a) has established new relationships. With the help of the second indicator, we aimed to capture to what extent (b) the top managers have social interactions with clients in the domestic market. Finally, the third indicator reflects Uzzi's (1997) notion that business relationships are characterized by the fact that (c) companies often solve problems 
together. Similarly, to measure "international business relationships," respondents answered the same questions based on the same indicators, but with a focus on the international market.

\section{"Table 1 goes about here"}

Opportunity knowledge. Two "opportunity knowledge" constructs are reflected in three indicators dealing with the extent to which the RYV received the following from international and domestic business relationships respectively: (a) new technological ideas, (b) new business opportunities and ideas, and (c) marketing knowledge. Obtaining technological ideas from business partners implies that they could be of use to the firm's customers. Thus, there is a market for the innovation as the idea comes from those who will use the innovation. The second indicator captures the acquired knowledge about opportunities and useful ideas in a business context. It reflects the "newness" dimension of opportunity, which is in line with Mainela, Puhakka, and Servais (2014). The third indicator reflects firms' capability to understand the market and to promote and sell the innovated product in the marketplace.

New product development. The self-report scale is the primary measure for new product development in existing studies (e.g., Zhang and Li 2010). As the unit of analysis is the RYV, we follow these studies that assess such ventures with the amount of innovative activity resulting in new product development (Knight and Cavusgil 2004). We are also interested in how efficiently the new venture develops new products and technology. We adapted previous work (Fey and Birkinshaw 2005) and used a three-indicator, seven-point Likert-based construct that reflects the three elements of the concept: the time-to-market, 
the quality of the R\&D activities, and the commercialization of the innovation. The respondents were therefore asked to assess firms' performance in relation to industry competitors in terms of (a) bringing in new products to market quickly, (b) breakthrough in $\mathrm{R} \& \mathrm{D}$, and (c) releasing new technology onto the market.

Control variables. We added nine controls. Firms' political relationships with government officials at different levels of government and in regulatory agencies are of particular importance in emerging markets (Luo, Huang, and Wang 2012) and are relevant to firms' innovation performance (Sheng et al. 2011). Therefore, we controlled for the influence of RYVs' political relationships. We operationalized "political relationships” by drawing on previous work (Luo, Huang, and Wang 2012).

Firm age, size, and R\&D investment are important indicators that are conventionally used to differentiate firms' innovation performance (Huergo and Jaumandreu 2004). Firm size and R\&D investment are particularly used to represent firms' absorptive capacity, which has an impact on firms' innovation. We measured firm age by subtracting the firm's founding year from 2013. Firm size is calculated as the number of employees. R\&D investment is measured as the $R \& D$ budget in relation to total sales.

In light of the fact that some RYVs may pay more attention to international markets, we controlled for the level of internationalization by employing the share of sales from international markets. We also controlled for the location of the firms (1 for big cities, 0 otherwise), because firms located in big cities may have access to better infrastructure and supportive resources. Some firms in the sample are solely owned by the returnee founder, whereas others have diverse ownership structures (e.g., venture capital, other firms) that may provide additional supports. Therefore, we controlled for ownership as a dummy variable ( 1 for sole ownership, 0 otherwise). As the firms belong to different segments of 
the high-tech industry, we controlled for industry-specific effects by introducing dummy variables for firms from electronics (66 or 33\%), information technology (54 or 27\%), biotech and medical (35 or 17.5\%), new energy ( 29 or $14.5 \%$ ), and new materials (16 or $8 \%)$. Moreover, we controlled for the international experience variance of returnee entrepreneurs as this factor may determine their R\&D capabilities (Liu, Lu et al. 2010). It is measured according to the number of years the returnee entrepreneurs have spent abroad.

\section{Data analysis technique}

The model was estimated by using covariance-based Structural Equation Modeling (SEM) with LISREL software. We chose the SEM technique because it can handle multiple relationships among constructs simultaneously, which enables us to disentangle the concurrent influence on new product development of international and domestic business relationships and opportunity knowledge of RYVs.

\section{ANALYSIS AND RESULTS}

\section{Measure validation}

Before testing the hypotheses, we assessed the reliability and validity of the constructs. First, the results of an exploratory factor analysis indicated that all the items loaded onto their designated constructs without cross- or low-factor loading (Ju et al. 2018). Second, we conducted a confirmatory factor analysis to assess the measurement model including domestic and international business relationships, domestic and international opportunity knowledge, new product development and political relationships (Jöreskog and Sörbom 1993). The $C h i$-square statistic is significant $\left(\chi^{2}(120)=264.69, p<.001\right)$, which is not surprising because of the test's sensitivity to sample size. Nevertheless, all other fit indices 
(comparative fit index $[\mathrm{CFI}]=0.95$; non-normed fit index $[\mathrm{NNFI}]=0.94$; root mean square error of approximation $[$ RMSEA] $=0.078)$ indicate a good model fit $($ Bentler 1990).

Table 1 presents the standardized loadings on the corresponding constructs, the composite reliability values, and the AVEs for each construct. All items load heavily on their designated constructs (standardized loading $\geq 0.66)$ and are significant $(\mathrm{t} \geq 8.38$ ), providing support for convergent validity. In addition, all the AVE values are over the threshold point of 0.50, which also support convergent validity (Fornell and Larcker 1981). The construct reliability values for all constructs were appropriate (Hair et al. 2006), ranging from 0.78 to 0.89 (see column 5 in Table 1 ). Table 2 reports the square root of the AVE for each latent variable along the diagonal, which are greater than the corresponding inter-construct correlations in the off-diagonal elements, and therefore support the discriminant validity of the constructs (Hair et al. 2006). Based on the above test results, our measures present adequate measurement properties and, thus, can be used for hypothesis-testing purposes.

\section{"Table 2 goes about here"}

\section{Tests of hypotheses}

To test the hypothesized relations and, specifically, to test the latent constructs' interactions, we applied the two-step single indicant method (Ping 1996). First of all, we standardized each observed variable in order to diminish potential multicollinearity issues. We then calculated each interaction term's single indicant along with their respective loadings, and measurement errors (Ping 1996), and entered the indicants, their loadings and measurement errors into the structural model. As presented in Table 3, the results revealed 
that five out of nine hypotheses are empirically supported. Thus, RYVs' domestic and international business relationships are positively associated, respectively, with the obtaining of domestic opportunity knowledge (H1a) $(\gamma=0.74, p<0.001)$ and international opportunity knowledge $(\mathrm{H} 1 \mathrm{~b})(\gamma=0.58, p<0.001)$. The interaction of international and domestic business relationships is negatively associated with the obtaining of international opportunity knowledge (H1c) $(\gamma=-0.26, p<0.001)$.

International opportunity knowledge $(\mathrm{H} 2 \mathrm{~b})(\gamma=0.32, p<0.05)$ and domestic business relationships $(\mathrm{H} 3 \mathrm{a})(\gamma=0.77, p<0.05)$ are positively associated with new product development. However, the relation between domestic opportunity knowledge and new product development $(\mathrm{H} 2 \mathrm{a})(\gamma=-0.22)$ and between international business relationships and also new product development $(\mathrm{H} 3 \mathrm{~b})(\gamma=-0.21)$ are not supported. The interaction of international and domestic business relationships $(\mathrm{H} 3 \mathrm{c})(\gamma=0.24)$, and the interaction of international and domestic opportunity knowledge $(\mathrm{H} 2 \mathrm{c})(\gamma=-0.22)$ do not show any significant relation with new product development. In addition, all control variables are not significant, and there were no substantial changes in path coefficients when control variables were included or excluded. Finally, the goodness-of-fit indices show a good model fit $($ Chi-square $=498.66 ; d . f .=291 ; R M S E A=0.060 ; C F I=0.93 ; N N F I=0.90)$.

\section{"Table 3 goes about here"}

Opportunity knowledge can also be considered to be a mechanism for conveying the effects of business relationships on new product development. The non-significant relation between international business relationships and new product development may be due to 
the mediating effect of international opportunity knowledge. Therefore, we empirically tested the mediating effects of domestic and international opportunity knowledge.

We followed the LISREL-specific suggestions offered by Lau and Cheung (2012), and applied the bootstrapping procedure to examine the indirect effects (Lau and Cheung 2012). By drawing on the coefficients of the direct paths (a, b, c, d) (see Figure 1), we calculated the product of the direct paths that form the indirect paths of $\mathrm{DBR} \rightarrow \mathrm{DOK} \rightarrow \mathrm{NPD}$, and IBR $\rightarrow \mathrm{IOK} \rightarrow \mathrm{NPD}$ (including ab and $\mathrm{cd}$ ). We assessed the significance of indirect effects with bias-corrected percentile bootstrap (Lau and Cheung 2012), which gave rise to a $95 \%$ confidence interval (CI) for "ab" and "cd" respectively. If the interval for an indirect effect does not include zero, it receives support that the indirect effect is significantly different from zero. The results (see Table 4) show that the mediating effect of international opportunity knowledge on the relationship between international business relationships and new product development is significant, while the mediating effect of domestic opportunity knowledge on the indirect path of DBR $\rightarrow \mathrm{DOK} \rightarrow \mathrm{NPD}$ is not significant.

"Table 4 goes about here"

\section{DISCUSSION AND IMPLICATIONS}

\section{Discussion}

Differing from most previous studies that focus on only one side of the story (either the international or the domestic aspect) of returnee entrepreneurship, our study sheds light on the concurrence of opportunity knowledge via international and domestic business 
relationships and their impact on new product development. We found that domestic and international business relationships are positively associated with opportunity knowledge. However, the effects of the obtained knowledge differ in terms of facilitating new product development. International opportunity knowledge directly influences new product development and fully mediates the influence of international business relationships on new product development. In contrast, domestic opportunity knowledge is not associated with new product development. Instead, domestic business relationships have a significantly direct effect on new product development. Furthermore, being active in both international and domestic relationships at the same time seems to constrain RYVs' capacity to obtain international opportunity knowledge.

These observations are critical as they suggest that the roles of international and domestic business relationships are different. In international markets, the relationships with business partners primarily provide the opportunity knowledge needed for innovation activities. In the domestic markets, the opportunity knowledge gained in relationships with local partners seems to be irrelevant for new product development. Instead, the exchange and acquisition of resources other than opportunity knowledge have a direct impact. Thus, our study demonstrates the importance of the domestic business relationships (Li et al. 2012) as they provide the complementary resources needed for innovation (Lin et al. 2019).

\section{Theoretical implications}

Our study advances the literature on returnee entrepreneurship and international marketing in two ways. First, we deliver a more complete spatial picture of RYVs by uncovering how RYVs benefit from their broad attachment across international and domestic markets and what types of business relationships and knowledge they can capitalize on in order to 
innovate. Previous research predominantly focuses on relationships in a single location (e.g., Liu, Lu et al. 2010), and therefore hardly captures the complexity of RYVs' business relationships in different locations. By taking into account the dual relationships distributed in different markets, we identified a configuration of domestic business relationships and international opportunity knowledge that drives RYVs' development of new products. This configuration reflects the transnational nature of RYVs' innovation activities and leads to the conclusion that business relationships and opportunity knowledge developed in different markets have dissimilar importance (Samiee et al. 2015). Therefore, we contribute to the literature by uncovering how the widely assumed advantage of dual business relationships (Lin et al. 2019) is conducive to innovation.

This advantage of dual relationships and knowledge is in contrast to the conventional assumption of born global literature (e.g., Chetty and Campbell-Hunt 2004) that the domestic market is relatively less important and can even be skipped for internationalization if the founders have international experience to underpin the international expansion of their ventures. It has been noted that domestic markets of RYVs (e.g. China) have built a solid infrastructure for the development of different industries and manufacturing sectors (Kenney et al. 2013), which is therefore important and gives RYVs a chance to better exploit their internationally sourced knowledge.

The benefits of domestic business relationships may also indicate the influence of the cultural and institutional environment on innovation (Luo et al. 2012). Although RYVs have developed multicultural perspectives, cultural background may continue to inform their thinking and behavior (Gao et al. 2018; Magnusson et al. 2013). It seems that returnee entrepreneurs understand the significance and implications of relationships when doing business domestically, and it also seems that they devote attention to developing domestic 
business relationships that can assist in their success, even in the high-tech industries where their firms possess technological competence. The domestic business relationships connect the firms to local networks and enable them to use physical resources, such as local production capacity and supply chains, in their efforts to innovate.

The trivial role of domestic opportunity knowledge relative to international opportunity knowledge may be because RYVs are more aware of the novelty and value of opportunity knowledge derived from international business relationships and are therefore inclined to pursue such opportunities (Bai, Johanson, and Martín Martín 2017) even if they move back with the intention of taking advantage of the domestic market. In particular, when the international opportunity knowledge relates to new technological opportunities and new business ideas, it is often novel and not yet available in the domestic market. It may also be the case that returnee entrepreneurs have a certain cognitive preference toward international opportunity knowledge because of their international experience. Returnee entrepreneurs tend to be influenced by the Western cultures and institutions, and they behave differently from domestic entrepreneurs at the early stage of business development (Liu and Almor 2016). As a consequence, RYVs may be unable to appreciate the significance of domestic opportunity knowledge and to recognize subsequent innovation opportunities until they have updated their understanding of the domestic market.

Our second contribution is about extending the paradox view of business relationships (Gao et al. 2018) by considering the interplay of dual relationships. By looking into the interaction effect of international and domestic business relationships, our study reveals the competing character of the relation between international and domestic relationships of young ventures and thus challenges previous literature that takes a balanced view of dual relationships (Chen and Tan 2009; Patel et al. 2014). Nurturing international 
and domestic business relationships at the same time results in a trade-off: the more active the RYV becomes in domestic business relationships, the less capable it is of obtaining opportunity knowledge from international business relationships. This implies that developing and maintaining dual business relationships is demanding for young ventures, especially given their scarce internal managerial resources. Young ventures may have to weigh the international and domestic relationships, as they not only complement each other in resource acquisition but may also compete with each other.

\section{Managerial implications}

The study has practical implications for RYVs and policy makers. Previous research shows that local firms are expected to improve their innovation performance if they build business relationships with RYVs (Liu, Lu et al. 2010). Based on our findings, we suggest that the development of domestic business relationships would enhance new product development of RYVs as well. Complementary resources from business relationships in domestic markets appear to be essential inputs for RYVs' innovation activities. As the procurement of such resources relies on business relationships with domestic partners, it is of significance that RYVs engage in networking activities in order to embed the business relationships in the domestic market, especially when the home country is characterized by large manufacturing capacities (e.g., China).

Yet, in light of the importance of developing and maintaining dual relationships simultaneously, RYVs need to apply a cost-efficient way to handle such dual tasks. As indicated in a recent study (Lin et al. 2019), such cost-efficient ways of developing domestic relationships could be starting ventures in locations where the returnee founder's pre-overseas domestic relationships can be better leveraged, or taking advantage of local 
top management team members who may serve as brokers. The varied benefits of different business networks, as well as the competition between dual relationships for resources, could also justify RYVs' asymmetric strategies across markets in order to better derive specific benefits from respective networks.

For policy makers, the study shows that supporting policies that promote both international and local collaborations may be instrumental in driving RYVs' new product development. In order to achieve such an aim, policy makers may develop more arrangements that are relevant, such as the initiation of networking events that provide a platform for facilitating resource exchange between RYVs and their local business partners. Similarly, policies that aim at supporting the development of RYVs' international networks, such as by setting up more flexible migration and visa regulations to facilitate returnee entrepreneurs' and foreign partners' mobility across borders, are expected to contribute to innovation through the acquisition of new opportunity knowledge.

\section{LIMITATIONS AND FUTURE RESEARCH DIRECTIONS}

Our study has some limitations that can be addressed in future studies. First, due to the small size and newness of RYVs, there are relatively few quantitative studies on these firms. In particular, longitudinal studies taking into account new product development and its determinants in different moments are necessary and could be applied to discover the dynamic nature of innovative efforts. Learning is often a long-term process, and there might be significant lead times between the specific knowledge gained and the innovation. Likewise, business relationships are dynamic in nature. Literature has investigated the development and maintenance of domestic relationships across different periods and locations (Lin et al. 2019). It would be an interesting research opportunity to study the 
dynamics of both international and domestic relationships simultaneously, particularly considering that the returnee founders become distant from international markets.

Second, although our study makes a distinction between the roles of international and domestic relationships, we do not consider whether the difference is due to the different constituents of relationships in international and domestic markets that result in different types of resource acquisition. As our findings imply, relationships developed in domestic markets are more likely to relate to components of suppliers and customer collaboration that entail the sharing of physical resources, and are less related to components of research and development collaborations that entail the sharing of knowledge. Therefore, future studies could develop deeper understandings by refining the types of dual relationship collaboration and exploring their effects. Other network characteristics, such as network size and scope, could also be examined and compared simultaneously in dual networks (Chen and Tan 2009). Consequently, we encourage international marketing scholars to more extensively investigate and compare business relationships in various markets.

Third, this study is based on empirical observations from only one economic zone of China, which thus compromises the generalizability of the findings. Although the Pearl River Delta Economic Zone has come to be known as the "world factory," most ventures concentrated there are privately owned firms in high-tech industries such as electronics, and information technology. Future research may focus on other countries and regions and may explore the industry effect more thoroughly by extending the present study to RYVs in other industries, such as heavy manufacturing. China is a context that has been investigated frequently, but the phenomenon of returnee young ventures has also become prevalent in other developing, emerging, and developed markets. The diversity of research contexts will 
provide a better understanding of how different business relationships and opportunity knowledge work in different markets.

Fourth, the present study could be extended by comparing RYVs with non-returnee firms and also by comparing different types of RYVs. RYVs are typically internationalized from inception, and their founders possess international experience. This implies that they are likely to be able to exploit the multinationality of their business relationships. Less internationally experienced SMEs are likely to miss this advantage. Further, the lack of RYVs with only domestic operations in our sample should be addressed in future studies. Scholars can check for and compare the drivers, levels, and characteristics of new product development in RYVs operating only domestically and operating only internationally. In addition, we need to carry out new studies that integrate several levels of analysis (the individual returnee, the firm, and even the country) to make progress in this area of inquiry.

Finally, new product development, as the result of building dual business relationships and obtaining opportunity knowledge, reflects a key aspect of RYVs' operational performance, which however may not necessarily lead to organizational performance (e.g., accounting performance) due to performance trade-offs (Katsikeas et al. 2016). Thus, a natural extension of our study is to investigate RYVs' organizational performance, whereby important new insights into the mechanism of operational performance on organizational performance may be offered to existing literature. 


\section{REFERENCES}

Andersson, Ulf, Ángels Dasí, Ram Mudambi, and Torben Pedersen (2016), “Technology, innovation and knowledge: The importance of ideas and international connectivity," Journal of World Business, 51(1), 153-162.

Armanios, Daniel E., Charles E. Eesley, Jizhen Li, and Kathleen M. Eisenhardt (2017), "How entrepreneurs leverage institutional intermediaries in emerging economies to acquire public resources," Strategic Management Journal, 38(7), 1383-1390.

Bai, Wensong, Martin Johanson, and Oscar Martín Martín (2017), "Knowledge and internationalization of returnee entrepreneurial firms," International Business Review, 26(4), 652-665.

Bentler, Peter M. (1990), "Comparative fit indexes in structural models," Psychological Bulletin, 107(2), 238-246.

Chang, Sea-jin, ArjenVan Witteloostuijn, and Lorraine Eden (2010), "From the editors: Common method variance in international business research," Journal of International Business Studies, 41(2), 178-184.

Chatterji, Aaron K., and Kira R. Fabrizio (2014), "Using users: When does external knowledge enhance corporate product innovation?" Strategic Management Journal, 35(10), 1427-1445.

Chen, Wenhong, and Justin Tan (2009), "Understanding transnational entrepreneurship through a network lens: Theoretical and methodological considerations," Entrepreneurship Theory and Practice, 33(5), 1079-1091.

Chetty, Sylvie, and Colin Campbell-Hunt (2004), "A strategic approach to internationalization: A traditional versus a 'born-global' approach," Journal of International marketing, 12(1), 57-81.

Chetty, Sylvie, Masoud Karami, and Oscar Martín Martín (2018), "Opportunity discovery and creation as duality: Evidence from small firms' foreign market entries," Journal of International Marketing, 26(3), 70-93.

Coviello, Nicole (2006), "The network dynamics in the international new venture," Journal of International Business Studies, 37(5), 713-731.

Dai, Ou, and Xiaohui Liu (2009), "Returnee entrepreneurs and firm performance in Chinese high-technology industries," International Business Review, 18(4), 373-386.

Eckhardt, Jonathan T., and Scott A. Shane (2003), "Opportunities and entrepreneurship," Journal of Management, 29(3), 333-349.

Ellis, Paul D. (2011), "Social ties and international entrepreneurship: Opportunities and constraints affecting firm internationalization," Journal of International Business Studies, 42(1), 99-127.

Fernhaber, Stephanie A., Patricia P. McDougall-Covin, and Dean A. Shepherd (2009), "International entrepreneurship: Leveraging internal and external knowledge sources," Strategic Entrepreneurship Journal, 3(4), 297-320.

Fey, Carl F., and Julian Birkinshaw (2005), "External sources of knowledge, governance mode, and R\&D performance," Journal of Management, 31(4), 597-621.

Fornell, Claes, and David F. Larcker (1981), "Evaluating structural equation models with unobservable variables and measurement error," Journal of Marketing Research, 18(1), $39-50$. 
Gao, Hongzhi, Monica Ren, and Qing Miao (2018), "Toward a yin-yang balancing perspective of relational (guanxi) gatekeeping in international exchange relationships in China," Journal of International Marketing, 26(2), 22-42.

Hair, Joseph F, William C Black, Barry J. Babin, and Rolph E. Anderson (2006), Multivariate Data Analysis (Vol. 6), Pearson Prentice Hall: Upper Saddle River, NJ.

Hoang, Ha, and Bostjan Antoncic (2003), "Network-based research in entrepreneurship: A critical review," Journal of Business Venturing, 18(2), 165-187.

Hoppner, Jessica J., David A. Griffith, and Ryan C. White (2015), "Reciprocity in relationship marketing: A cross-cultural examination of the effects of equivalence and immediacy on relationship quality and satisfaction with performance," Journal of International Marketing, 23(4), 64-83.

Huergo, Elena, and Jordi Jaumandreu (2004), "Firms' age, process innovation and productivity growth," International Journal of Industrial Organization, 22(4), 541-559.

Johanson, Jan, and Jan-Erik Vahlne (1977), "The internationalization process of the firma model of knowledge development and increasing foreign market commitments," Journal of international business studies, 8(1), 23-32.

Johanson, Jan, and Jan-Erik Vahlne (2009), "The Uppsala internationalization process model revisited: From liability of foreignness to liability of outsidership," Journal of International Business Studies, 40(9), 1411-1431.

Jöreskog, Karl G., and Dag Sörbom (1993), "LISREL 8: Structural Equation Modelling with the SIMPLIS Command Language," Erlbaum: Hillsdale, NJ.

Ju, Min, and Gerald Yong Gao (2017), "Relational governance and control mechanisms of export ventures: An examination across relationship length," Journal of International Marketing, 25(2), 72-87.

Ju, Min, Jason Lu Jin, and Kevin Zheng Zhou (2018), "How can international ventures utilize marketing capability in emerging markets? Its contingent effect on new product development," Journal of International Marketing, 26(4), 1-17.

Katsikeas, Constantine S., Dionysis Skarmeas, and Daniel C. Bello (2009), "Developing successful trust-based international exchange relationships," Journal of International Business Studies, 40(1), 132-155.

Katsikeas, Constantine S., Neil A. Morgan, Leonidas C. Leonidou, and G. Tomas M. Hult (2016), “Assessing performance outcomes in marketing," Journal of Marketing, 80(2), $1-20$.

Kenney, Martin, Dan Breznitz, and Michael Murphree (2013), "Coming back home after the sun rises: Returnee entrepreneurs and growth of high tech industries," Research Policy, 42(2), 391-407.

Knight, Gary A., and S. Tamar Cavusgil (2004), "Innovation, organizational capabilities, and the born-global firm," Journal of International Business Studies, 35(2), 124-141.

Knight, Gary A., and Peter W. Liesch (2016), "Internationalization: From incremental to born global," Journal of World Business, 51(1), 93-102.

Lau, Rebecca S., and Gordon W. Cheung (2012) "Estimating and comparing specific mediation effects in complex latent variable models," Organizational Research Methods, 15(1), 3-16.

Laursen, Keld, and Ammon Salter (2006), "Open for innovation: The role of openness in explaining innovation performance among UK manufacturing firms," Strategic Management Journal, 27(2), 131-150. 
Leiponen, Aija, and Constance E. Helfat (2010), "Innovation objectives, knowledge sources, and the benefits of breadth," Strategic Management Journal, 31(2), 224-236.

Leonidou, Leonidas C., Saeed Samiee, Bilge Aykol, and Michael A. Talias (2014), "Antecedents and outcomes of exporter-importer relationship quality: Synthesis, metaanalysis, and directions for further research," Journal of International Marketing, 22(2), 21-46.

Levin, Daniel Z., and Helena Barnard (2013), "Connections to distant knowledge: Interpersonal ties between more- and less-developed countries," Journal of International Business Studies, 44(7), 676-698.

Levinthal, Daniel A., and James G. March (1993), "The myopia of learning," Strategic Management Journal, 14(2), 95-112.

Li, Haiyang, Yan Zhang, Yu Li, Li-An Zhou, and Weiying Zhang (2012), "Returnees versus locals: Who perform better in China's technology entrepreneurship?" Strategic Entrepreneurship Journal, 6(3), 257-272.

Lin, Daomi, Jiangyong Lu, Xiaohui Liu, and Xue Zhang (2016), "International knowledge brokerage and returnees' entrepreneurial decisions," Journal of International Business Studies, 47(3), 295-318.

Lin, Daomi, Wei Zheng, Jiangyong Lu, Xiaohui Liu, and Mike Wright (2019), "Forgotten or not? Home country embeddedness and returnee entrepreneurship," Journal of World Business, 54(1), 1-13.

Lin, Xiaohua (2010), "The diaspora solution to innovation capacity development: Immigrant entrepreneurs in the contemporary world," Thunderbird International Business Review, 52(2), 123-136.

Liu, Xiaohui, Jiangyong Lu, Igor Filatotchev, Trevor Buck, and Mike Wright (2010), "Returnee entrepreneurs, knowledge spillovers and innovation in high-tech firms in emerging economies," Journal of International Business Studies, 41(7), 1183-1197.

Liu, Xiaohui, Mike Wright, and Igor Filatotchev (2015), "Learning, firm age and performance: An investigation of returnee entrepreneurs in Chinese high-tech industries," International Small Business Journal, 33(5), 467-487.

Liu, Xiaohui, Mike Wright, Igor Filatotchev, Ou Dai, and Jiangyong Lu (2010), "Human mobility and international knowledge spillovers: Evidence from high-tech small and medium enterprises in an emerging market," Strategic Entrepreneurship Journal, 4(4), 340-355.

Luo, Yadong, Ying Huang, and Stephanie L. Wang (2012), "Guanxi and organizational performance: A meta-analysis," Management and Organization Review, 8(1), 139-172.

Magnusson, Peter, Stanford A. Westjohn, Alexey V. Semenov, Arilova A. Randrianasolo, and Srdan Zdravkovic (2013), "The role of cultural intelligence in marketing adaptation and export performance," Journal of International Marketing, 25(2), 72-87.

Mainela, Tujia, Vesa Puhakka, and Per Servais (2014), "The concept of international opportunity in international entrepreneurship: A review and a research agenda," International Journal of Management Reviews, 16(1), 105-129.

Oviatt, Benjamin M., and Patricia P. McDougall (2005), "Defining international entrepreneurship and modeling the speed of internationalization," Entrepreneurship Theory and Practice, 29(5), 537-554.

Paparoidamis, Nicholas G., Constantine S. Katsikeas, and Ruben Chumpitaz (2019), "The role of supplier performance in building customer trust and loyalty: A cross-country examination," Industrial Marketing Management, 78(4), 183-197. 
Patel, Pankaj C., and Betty Conklin (2009), "The balancing act: The role of transnational habitus and social networks in balancing transnational entrepreneurial activities," Entrepreneurship Theory and Practice, 33(5), 1045-1078.

Patel, Pankaj C., Stephanie A. Fernhaber, Patricia P. McDougall-Covin, and Robert P. van der Have (2014), "Beating competitors to international markets: The value of geographically balanced networks for innovation," Strategic Management Journal, 35(5), 691-711.

Ping, Robert (1996), "Latent variable interaction and quadratic effect estimation: A two-step technique using structural equation analysis," Psychological Bulletin, 119 (January), 166-175.

Podsakoff, Philip M., Scott B. MacKenzie, Jeong-Yeon, Lee, and Nathan P. Podsakoff (2003), "Common method biases in behavioral research: A critical review of the literature and recommended remedies," Journal of Applied Psychology, 88(5), 879-903.

Pruthi, Sarika (2014), "Social ties and venture creation by returnee entrepreneurs," International Business Review, 23 (6), 1139-1152.

Qin, Fei and Saul Estrin (2015), "Does social influence span time and space? Evidence from Indian returnee entrepreneurs," Strategic Entrepreneurship Journal, 9(3), 226-242.

Rao, Raghunath Singh, Rajesh K. Chandy, and Jaideep C. Prabhu (2008), "The fruits of legitimacy: Why some new ventures gain more from innovation than others," Journal of Marketing, 72(4), 58-75.

Robson, Matthew J., Constantine S. Katsikeas, Bodo B. Schlegelmilch, and Barbara Pramböck (2019), "Alliance capabilities, interpartner attributes, and performance outcomes in international strategic alliances," Journal of World Business, 54(2), 137153.

Samiee, Saeed, Brian R. Chabowski and G. Tomas M. Hult (2015), "International relationship marketing: Intellectual foundations and avenues for further research," Journal of International Marketing, 23(4), 1-21.

Sheng, Shibin, Kevin Zheng Zhou, and Julie Juan Li (2011), "The effects of business and political ties on firm performance: Evidence from China," Journal of Marketing, 75(1), $1-15$.

Shu, Chengli, Albert L. Page, Shanxing Gao, and Xu Jiang (2012), "Managerial ties and firm innovation: Is knowledge creation a missing link?" Journal of Product Innovation Management, 29(1), 125-143.

Skarmeas, Dionysis, Athina Zeriti, and George Baltas (2016), "Relationship value: Drivers and outcomes in international marketing channels," Journal of International Marketing, 24(1), 22-40.

Uzzi, Brian (1997), "Social structure and competition in interfirm networks: The paradox of embeddedness," Administrative Science Quarterly, 42(1), 35-67.

Wang, Huiyao, and Miao Lv (2013), Annual Report on the Development of Chinese Returnee (2013) No.2, Beijing.

Williams, Larry J., Nathan Hartman, and Flavia Cavazotte, (2010), "Method variance and marker variables: A review and comprehensive CFA marker technique," Organizational Research Methods, 13(3), 477-514.

Wright, Mike, Xiaohui Liu, Trevor Buck, and Igor Filatotchev (2008), "Returnee entrepreneurs, science park location choice and performance: An analysis of hightechnology SMEs in China," Entrepreneurship: Theory and Practice, 32(1), 131-155. 
Wu, Jie, and Zefu Wu (2014), "Local and international knowledge search and product innovation: The moderating role of technology boundary spanning," International Business Review, 23(3), 542-551.

Yang, Man, and Peter Gabrielsson (2018), "The interface of international marketing and entrepreneurship research: Review, synthesis, and future directions," Journal of International Marketing, 26(4), 18-37.

Yli-Renko, Helena, and Ramkumar Janakiraman (2008), "How customer portfolio affects new product development in technology-based entrepreneurial firms," Journal of Marketing, 72(5), 131-148.

Zhang, Haisu, Chengli Shu, Xu Jiang, and Alen J. Malter AJ (2010), "Managing knowledge for innovation: The role of cooperation, competition, and alliance nationality," Journal of International Marketing, 8(4), 74-94.

Zhang, Yan, and Haiyang Li (2010), "Innovation search of new ventures in a technology cluster: The role of ties with service intermediaries," Strategic Management Journal, 31(1), 88-109.

Zhou, Lianxi, Wei-ping Wu, and Xueming Luo (2007), "Internationalization and the performance of born-global SMEs: The mediating role of social networks," Journal of International Business Studies, 38(4), 673-690. 


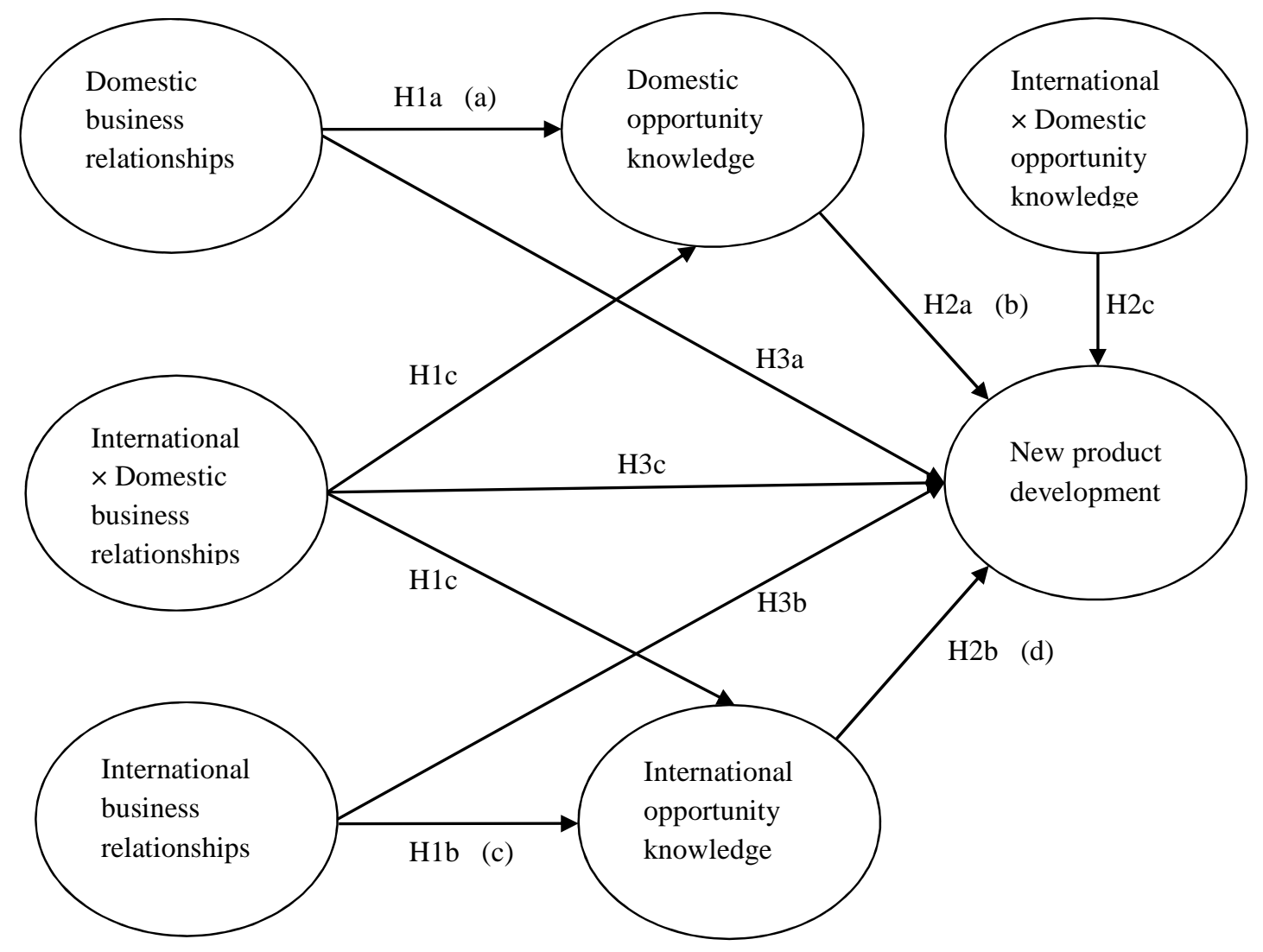

FIGURE 1. A network model of returnee young ventures' innovation drivers 


\section{Table 1. Operationalization of the constructs}

\begin{tabular}{|c|c|c|c|c|c|}
\hline Construct/ Items & Mean & S.D. & $\begin{array}{l}\text { Standardized } \\
\text { loadings }\end{array}$ & $\mathbf{C R}$ & AVE \\
\hline Domestic Business Relationships (DBR) & & & & 0.78 & 0.54 \\
\hline Our firm has established new relationships & 5.46 & 1.05 & 0.83 & & \\
\hline Our top managers have social interactions with clients & 5.48 & 1.08 & 0.70 & & \\
\hline Companies often solve problems together & 5.67 & 0.98 & 0.67 & & \\
\hline Domestic Opportunity Knowledge (DOK) & & & & 0.86 & 0.67 \\
\hline New technological ideas & 5.40 & 1.16 & 0.78 & & \\
\hline New business opportunities and ideas & 5.36 & 1.10 & 0.87 & & \\
\hline Marketing knowledge & 5.42 & 1.15 & 0.80 & & \\
\hline International Business Relationships (IBR) & & & & 0.89 & 0.73 \\
\hline Our firm has established new relationships & 4.63 & 1.62 & 0.92 & & \\
\hline Our top managers have social interactions with clients & 4.79 & 1.60 & 0.81 & & \\
\hline Companies often solve problems together & 4.98 & 1.65 & 0.83 & & \\
\hline International Opportunity Knowledge (IOK) & & & & 0.87 & 0.69 \\
\hline New technological ideas & 5.75 & 1.38 & 0.84 & & \\
\hline New business opportunities and ideas & 5.60 & 1.37 & 0.83 & & \\
\hline Marketing knowledge & 5.40 & 1.42 & 0.82 & & \\
\hline New Product Development (NPD) & & & & 0.79 & 0.56 \\
\hline Bringing in new products to market quickly & 5.46 & 1.18 & 0.66 & & \\
\hline RD breakthrough & 5.39 & 1.26 & 0.81 & & \\
\hline Releasing new technology to market & 5.46 & 1.16 & 0.77 & & \\
\hline Political Relationships (PR) & & & & 0.89 & 0.73 \\
\hline We have frequent contacts with different levels of government & 4.09 & 2.12 & 0.77 & & \\
\hline Information exchange between the firm and government and related regulators is easy & 4.34 & 1.85 & 0.92 & & \\
\hline Government and related regulators help firms solve problems & 4.56 & 1.62 & 0.86 & & \\
\hline Firm Age & 4.41 & 3.17 & 1.00 & 1.00 & 1.00 \\
\hline Firm Size & 37.35 & 38.62 & 1.00 & 1.00 & 1.00 \\
\hline RD Investment (RDI) & 0.58 & 0.39 & 1.00 & 1.00 & 1.00 \\
\hline Level of Internationalization & 0.24 & 0.23 & 1.00 & 1.00 & 1.00 \\
\hline Location & 0.64 & 0.48 & 1.00 & 1.00 & 1.00 \\
\hline Ownership & 0.84 & 0.37 & 1.00 & 1.00 & 1.00 \\
\hline Returnee Experience (RE) & 7.82 & 5.58 & 1.00 & 1.00 & 1.00 \\
\hline
\end{tabular}

All standardized coefficient loadings are significant at $p<0.01$

$\mathrm{CR}=$ Construct reliability; $\mathrm{AVE}=\mathrm{Average}$ variance extracted for each multi-item construct in the research model 
Table 2. Correlation matrix of constructs $(N=200)$

\begin{tabular}{|c|c|c|c|c|c|c|c|c|c|c|c|c|c|}
\hline Construct & (1) & (2) & (3) & (4) & (5) & (6) & (7) & (8) & (9) & (10) & (11) & (12) & (13) \\
\hline (1) Domestic Business Relationships & 0.73 & & & & & & & & & & & & \\
\hline (2) Domestic Opportunity Knowledge & $0.57 * *$ & 0.82 & & & & & & & & & & & \\
\hline (4) International Opportunity Knowledge & $0.19 * *$ & $0.32 * *$ & $0.53 * *$ & $\mathbf{0 . 8 3}$ & & & & & & & & & \\
\hline (5) New product development & $0.41 * *$ & $0.27 * *$ & 0.12 & $0.26 * *$ & 0.75 & & & & & & & & \\
\hline (6) Political Relationships & $0.37 * *$ & $0.31 *$ & $-0.29 * *$ & $-0.22 * *$ & $0.20 * *$ & 0.85 & & & & & & & \\
\hline (7) Firm Age & -0.03 & -0.05 & 0.02 & -0.06 & -0.05 & -0.13 & 1.00 & & & & & & \\
\hline (8) Firm Size & 0.00 & 0.05 & 0.03 & -0.002 & -0.002 & -0.05 & $0.45^{* *}$ & 1.00 & & & & & \\
\hline (9) RD Investment & 0.07 & -0.09 & -0.01 & 0.03 & 0.07 & -0.06 & -0.08 & -0.08 & 1.00 & & & & \\
\hline (10) Level of internationalization & $-0.28 * *$ & -0.03 & $0.16^{*}$ & 0.08 & -0.14 & -0.12 & $0.15^{*}$ & $0.19 * *$ & -0.02 & 1.00 & & & \\
\hline (11) Location & -0.05 & -0.09 & -0.04 & -0.03 & -0.04 & $-0.15^{*}$ & $0.16^{*}$ & $0.19 * *$ & -0.00 & -0.07 & 1.00 & & \\
\hline (12) Ownership & $-0.14 *$ & -0.06 & 0.01 & -0.09 & -0.06 & -0.03 & -0.02 & $-0.15^{*}$ & 0.01 & -0.002 & 0.03 & 1.00 & \\
\hline (13) Returnee Experience & 0.01 & 0.07 & -0.01 & 0.004 & 0.02 & 0.09 & -0.002 & -0.04 & -0.06 & 0.04 & 0.08 & -0.05 & 1.00 \\
\hline
\end{tabular}

$* p<.05 ; * * p<.01$ (level of confidence, two-tailed tests)

Diagonal values in bold are the square roots of the variance shared between the constructs and their measurements.

For discriminant validity to be established, the diagonal elements must be greater than the off-diagonal elements in the corresponding rows and columns. 
Table 3. Model's paths, points of significance and results

\begin{tabular}{|c|c|c|c|}
\hline \multirow[b]{2}{*}{ Hypotheses } & \multicolumn{3}{|l|}{ tandardized } \\
\hline & \multicolumn{3}{|l|}{ Estimate } \\
\hline H1a Domestic business relationships $\rightarrow$ Domestic opportunity knowledge & 0.74 & $6.79 * * *$ & Supported \\
\hline H1b International business relationships $\rightarrow$ International opportunity knowledge & 0.58 & $7.99 * * *$ & Supported \\
\hline \multicolumn{4}{|l|}{ H1c International $\times$ Domestic business relationships $\rightarrow$ International opportunity } \\
\hline \multicolumn{4}{|l|}{ knowledge } \\
\hline H2a Domestic opportunity knowledge $\rightarrow$ New product development & -0.22 & -1.58 & Not supported \\
\hline $\mathrm{H} 2 \mathrm{~b}$ International opportunity knowledge $\rightarrow$ New product development & 0.32 & $2.88 * *$ & Supported \\
\hline $\mathrm{H} 2 \mathrm{c}$ International $\times$ Domestic opportunity knowledge $\rightarrow$ New product & -0.22 & -1.29 & Not supported \\
\hline development & & & \\
\hline H3a Domestic business relationships $\rightarrow$ New product development & 0.77 & $2.51 * *$ & Supported \\
\hline $\mathrm{H} 3 \mathrm{~b}$ International business relationships $\rightarrow \mathrm{New}$ product development & -0.21 & -1.20 & Not supported \\
\hline $\begin{array}{l}\text { H3c International } \times \text { Domestic business relationships } \rightarrow \text { New product } \\
\text { development }\end{array}$ & 0.24 & 1.50 & Not supported \\
\hline
\end{tabular}

Controls: Political relationships (0.04), Firm age (-0.02), Firm size (0.01), RD investment (-0.01), Level of internationalization (-0.05), Location (-0.02), Ownership (0.02), Industries (Electronics, 0.16; Information technology, 0.11; Biotech and medical, 0.11; New energy, 0.11), Returnee experience (0.02) all are not significant.

$* \mathrm{p}<.05 ; * * \mathrm{p}<.01 ; * * * \mathrm{p}<.001$ 
Table 4. Mediating test results

\begin{tabular}{|c|c|c|c|}
\hline \multicolumn{4}{|l|}{ Mediating path } \\
\hline & \multirow[t]{2}{*}{ Point estimate } & \multicolumn{2}{|c|}{$\begin{array}{c}\text { Correct bias percentile bootstrap } 95 \% \\
\text { confidence interval }^{1}\end{array}$} \\
\hline & & Lower & Upper \\
\hline $\mathrm{DBR} \rightarrow \mathrm{DOK} \rightarrow \mathrm{NPD}(\mathrm{ab})$ & -0.1628 & -0.6079 & 0.2347 \\
\hline $\mathrm{IBR} \rightarrow \mathrm{IOK} \rightarrow \mathrm{NPD}(\mathrm{cd})$ & 0.1856 & 0.1172 & 0.3448 \\
\hline
\end{tabular}


Appendix 1. Characteristics of the firms in the sample

\begin{tabular}{|c|c|c|c|c|c|}
\hline & Mean & \multicolumn{2}{|c|}{ Min } & \multicolumn{2}{|l|}{ Max } \\
\hline Firm size $^{1}$ & 37.35 & \multicolumn{2}{|c|}{4} & \multicolumn{2}{|l|}{200} \\
\hline Firm age & 4.41 & \multicolumn{2}{|c|}{2} & \multicolumn{2}{|l|}{18} \\
\hline Firm sales ${ }^{2}$ & 24.46 & \multicolumn{2}{|c|}{1} & \multicolumn{2}{|l|}{80} \\
\hline No. of international patents & 1.1 & \multicolumn{2}{|c|}{0} & \multicolumn{2}{|l|}{20} \\
\hline Timing of internationalization ${ }^{3}$ & 1.76 & \multicolumn{2}{|c|}{0} & \multicolumn{2}{|l|}{13} \\
\hline No. of international markets & 5.6 & \multicolumn{2}{|c|}{1} & \multicolumn{2}{|l|}{56} \\
\hline Share of international sales ${ }^{4}$ & $23.57 \%$ & \multicolumn{2}{|c|}{$1 \%$} & \multicolumn{2}{|l|}{$95 \%$} \\
\hline \multirow[t]{2}{*}{ Location } & Big cities $^{5}$ & & & \multicolumn{2}{|c|}{ Small cities } \\
\hline & 128 & & & \multicolumn{2}{|l|}{72} \\
\hline \multirow[t]{2}{*}{ Type of industries } & Electronics & $\begin{array}{l}\text { Information } \\
\& \text { tech }\end{array}$ & $\begin{array}{l}\text { Biotech and } \\
\text { medical }\end{array}$ & New energy & $\begin{array}{l}\text { New } \\
\text { materials }\end{array}$ \\
\hline & $66(33 \%)$ & $54(27 \%)$ & $35(17.5 \%)$ & $29(14.5 \%)$ & $16(8 \%)$ \\
\hline Returnees' education level & $\begin{array}{l}\mathrm{PhD} \\
132(66 \%)\end{array}$ & \multicolumn{2}{|c|}{ Master } & \multicolumn{2}{|c|}{ Bachelor } \\
\hline
\end{tabular}

${ }^{1}$ Size measured as number of employees.

2 Measured in RMB million.

${ }^{3}$ No. of years gap between the first year having international sales and the year of firm establishment.

${ }^{4}$ Measured in relation to total sales in 2012.

${ }^{5}$ Big cities refer to Guangzhou and Shenzhen with a population of over 20 million. 


\section{Appendix 2. CFA marker technique results}

\begin{tabular}{llll}
\hline Model & $\chi^{2}$ & $d f$ & CFI \\
\hline 1.CFA & 320.69 & 149 & 0.95 \\
2. Baseline & 366.21 & 157 & 0.93 \\
3. Method-C & 346.79 & 156 & 0.94 \\
4. Method-U & 321.05 & 142 & 0.95 \\
5. Method-R & 333.48 & 156 & 0.93 \\
Chi-Square Model Comparison Tests & & & \\
MModels & $\Delta \chi^{2}$ & $\triangle d f$ & Chi-Square Critical Value; 0.05 \\
1.Baseline vs. Method-C & $19.42^{*}$ & 1 & 3.84 \\
2.Method-C vs. Method-U & $25.74^{*}$ & 14 & 23.68 \\
3.Method-U vs. Method-R & 12.43 & 14 & 23.68 \\
\hline
\end{tabular}

* if $\Delta \chi^{2}$ is bigger than the Chi-square critical value, the Chi-square difference is significant.

$\mathrm{CFI}=$ comparative fit index

CFA model: A normal confirmatory factor analysis (CFA) that allows a complete set of correlations among the six investigated constructs and the marker variable.

Baseline model: Correlations between the marker construct and other constructs are forced to zero.

Method-C model: From the baseline model, all items of investigated construct load on the marker construct, and the factor loadings are constrained to be equal.

Method-U model: From the baseline model, all items of investigated construct load on the marker construct, and the factor loadings are freely estimated.

Method-R model: Based on the Method-R model, the correlations of investigated constructs are constrained to its unstandardized value from the baseline model. 